\title{
FOUR NEW SPECIES OF THRAUSTOCHYTRIUM FROM ANTARCTIC REGIONS, WITH NOTES ON THE DISTRIBUTION OF ZOOSPORIC FUNGI IN THE ANTARCTIC MARINE ECOSYSTEMS ${ }^{1}$
}

\author{
Günther Bahnweg and Frederick K. Sparrow, Jr. \\ Department of Botany, University of Michigan, Ann Arbor 48104
}

\begin{abstract}
A B S T R A C T
New species of the obligately marine Thraustochytriaceae Sparrow were discovered in subantarctic and antarctic waters of the southeastern Indian Ocean, the southwestern Pacific Ocean, and the antarctic Ross Sea during two cruises of the research vessel USNS ELTANIN. The life cycles of four species of Thraustochytrium in seawater-pollen and/or seawater-brine shrimp larvae cultures are described. Thraustochytrium antarcticum sp. nov. develops sporangia that may proliferate from a single basal rudiment. Flagellated zoospores are liberated from the sporangium upon complete disintegration of the sporangial wall at maturity. Thraustochytrium rossii $\mathrm{sp}$. nov. and $T$. kerguelensis $\mathrm{sp}$. nov. are both similar in that they develop sporangia that may proliferate from more than one basal rudiment. The latter species releases flagellated zoospores upon complete disintegration of the sporangial wall, but the former species liberates a mass of individually immobile zoospores from the sporangium. These remain quiescent for several hours before they swim away one after another. The protoplast of Thraustochytrium amoeboidum sp. nov. leaves the sporangium through a pore as an amoeboid body which then gives rise to nonflagellated amoebospores by successive bipartitioning. Laterally biflagellate thraustochytrioid zoospores were also observed, but the way in which they are formed remains to be determined. Zoosporic and aplanosporic phycomycetes were recovered from water samples collected in the Subtropical, Subantarctic, and Antarctic Zones of the Southern Ocean. Highest numbers of phycomycete propagules were found in antarctic waters near the Antarctic Convergence during ELTANIN's Cruise 51. In the Subtropical and Subantarctic (but not in the Antarctic) Zones fungal population densities increased with proximity to continents or islands. At each station where phycomycetes were recovered, highest numbers of propagules were generally found in the surface layers (25-250 $\mathrm{m}$ ) of the ocean below the photic zone (lower limit $30-60 \mathrm{~m}$ ). This peculiar distribution may indicate that phycomycetes are engaged in decomposing substances derived from the photic zone.
\end{abstract}

REPORTS ON the occurrence of phycomycetes in antarctic and subantarctic regions are scarce, and those that exist are primarily concerned with terrestrial and freshwater fungi (Harder and Persiel, 1962; Sugiyama, et al., 1967; Paterson and Knox, 1972; Paterson and Rooney, 1972). Studies on antarctic marine phycomycetes have been completely neglected, although phycomycetes, particularly those belonging to the marine family Thraustochytriaceae Sparrow (1936) have been found in all other major oceans and their tributaries (Artemtchuk, 1972; Fuller, Fowles, and

\footnotetext{
${ }^{1}$ Received for publication 30 July 1973 .

We wish to express our sincere appreciation for the excellent technical assistance of Mrs. Evelyn Bahnweg during field and laboratory studies. Mr. Kurt E. Nehring, Georg-August-Universität Göttingen, W. Germany, assisted on ELTANIN's Cruise 51. The Latin translations were kindly provided by Dr. Robert H. Brophy, III, of the Department of Classical Studies, The University of Michigan, Ann Arbor. This study was supported by a grant from the National Science Foundation (No. GA 16097) through the Office of Polar Programs.
}

McLaughlin, 1964; Gaertner, 1968a, b, c, 1969; Höhnk, 1966; Kobayashi and Ookubo, 1953; Schneider, 1968, 1971; Sparrow, 1936, 1968, 1969; Ulken, 1966).

In the austral summer of $1970 / 71$ a study of antarctic marine phycomycetes was initiated during Cruise 46 of the USNS ELTANIN in the southeastern Indian Ocean (Bahnweg and Sparrow, 1971). The mycological investigation of the Antarctic Ocean was continued during ELTANIN's Cruise 51 in the southwestern Pacific Ocean and in the antarctic Ross Sea in January and February of 1972 (Bahnweg and Sparrow, 1972a). Data were collected by the senior author.

All phycomycetes recovered from the high seas and from bottom sediment samples on the two cruises of the ELTANIN to the Antarctic belong to the Thraustochytriaceae Sparrow. Members of this family develop thalli that are composed of vegetative and reproductive parts and are hence eucarpic. The vegetative portion of the thallus is a fine delicately branched endobiotic rhizoidal 
system ${ }^{2}$ anchoring to the substrate the epibiotic reproductive part. The latter is a sporangium which at maturity gives rise to either laterally biflagellate zoospores (Thraustochytrium Sparrow, Japonochytrium Kobayashi \& Ookubo, and Schizochytrium Goldstein \& Belsky) or to aplanospores (Aplanochytrium Bahnweg \& Sparrow). A basal rudiment is delimited prior to or at zoospore cleavage in some species of Thraustochytrium. The rudiment remains behind after zoospore liberation and by enlargement gives rise to another sporangium.

None of the four species of marine phycomycetes discovered during ELTANIN Cruises 46 and 51 has previously been described. A fifth phycomycetaceous fungus from subantarctic waters, Aplanochytrium kerguelensis Bahnweg \& Sparrow, also considered a member of the Thraustochytriaceae, was described in a previous publication (Bahnweg and Sparrow, 1972b).

MATERIALS AND METHODS-Water samples were taken with Niskin sterile bag samplers (Niskin, 1962 ) which yielded about 4 liters of seawater per sample. At each ship station up to 12 samples were obtained from different depths. Aliquots of $50-500 \mathrm{ml}$ (subtropical and subantarctic regions) and of 500-1000 ml (antarctic regions) of each sample were filtered through Millipore membrane

\footnotetext{
${ }^{2}$ Perkins $(1972,1973 a)$ has shown, however, that the "rhizoids" of members of the Thraustochytriaceae are not homologous with true rhizoids of chytrids, i.e., they are not delimited by a cell wall, they do not contain cytoplasmic organelles, and they actually form net-like rather than arborescent structures and are hence referred to (by Perkins) as "ectoplasmic nets." "Pseudorhizoids" is a more recognizable mycological term (F. K. S.).
}

filters ( $47 \mathrm{~mm}$ diam, $0.8 \mu \mathrm{m}$ pore size). During ELTANIN Cruise 51 about half of each water sample was filtered through glass fiber filters (47 mm diam) while the other half was processed by membrane filtration. The filters were transferred to a nutrient agar (tryptone $5 \mathrm{~g}$, yeast extract $2.5 \mathrm{~g}$, glucose $1 \mathrm{~g}$, agar $14 \mathrm{~g}$, seawater 1000 $\mathrm{ml}$ ) and incubated at 8-12 C. At selected stations during both ELTANIN cruises, some water samples were entirely or partially processed by a modified MPN-pollen grain method (Gaertner, 1968a) employing pine pollen as a bait. Filters were periodically examined for fungal colonies. These appeared as early as two days, and generally not later than 3-4 weeks after collection and incubation. The colonies on each filter were counted, representative colonies examined microscopically, and the number of fungal propagules per liter seawater calculated for each sample. Samples of pollen from the MPN-pollen grain set ups were examined microscopically for the presence of fungal thalli after two, four, and eight weeks of incubation. Of the three quantitative methods employed in this study (membrane filtration, glass fiber filters, MPN-pollen grain technique) the glass fiber filtering technique yielded consistently highest numbers. Bottom sediment samples collected by either gravity or Phleger corers were processed with the aid of special quantitative forceps (Gaertner, 1968a). Aliquots of $0.1 \mathrm{ml}$ bottom sediment were spread on the surface of nutrient agar plates. Aliquots of $0.2 \mathrm{ml}$ sediment were added to bottles containing $25 \mathrm{ml}$ sterile seawater, and pine pollen was added as a bait.

At some stations sampling of the water column was repeated (up to three times) in order to ob-

Fig. 1-4. 1. Thraustochytrium rossii. (A) young sporangium with one basal rudiment; (B) more rudiments are successively cleaved out of the cytoplasm as the sporangium enlarges; (C) mature sporangium containing a large number of rudiments, the remaining cytoplasm cleaved into spores; (D) nonflagellated spores emerging through deliquescing apical portion of sporangium wall; (E) flagellated zoospores dispersing after complete disintegration of sporangial wall; $(F)$ enlarging basal rudiment with cytoplasm cleaved entirely into spores; ( $\left.F^{*}\right)$ enlarging basal rudiment containing new rudiments cleaved from its cytoplasm; (G) mass of immobile spores set free by distintegration of the rudiment wall. 2. Thraustochytrium kerguelensis. (A) mature sporangium containing several basal rudiments, the remainder of the cytoplasm cleaved into spores; (B) flagellated zoospores swimming away after complete disintegration of the sporangial wall. 3. Thraustochytrium antarcticum. (A) mature sporangium; (B) flagellated zoospores leaving basal rudiment behind after complete disintegration of the sporangial wall. 4 . Thraustochytrium amoeboidum. (A) mature sporangium with the protoplast retracted from the sporangial wall; (B) protoplast emerging from sporangium through a pore in the wall; (C) amoeboid protoplast; (D) euglenoid protoplast; (E) rounded up protoplast, $(F)$ dividing protoplast; $(G)$ dividing protoplast after second division; $(H)$ amoebospores; $\left(\mathrm{H}^{*}\right)$ young sporangium developing from daughter cell without previous formation of amoebospore or zoospores; (I) young sporangium developing from encysted amoebospore; (I*) zoospores.

Fig. 5-14.-Fig. 5-10. Thraustochytrium rossii sp. nov. 5. Seawater mount of colony from membrane filter. 6. Thalli with thick hyaline walls (arrows) in liquid nutrient medium. 7. Sporangium with several basal rudiments (BR). 8. Discharge of a mass of individually immobile zoospores. 9. Cluster of basal rudiments remaining behind after discharge. 10. Enlarging basal rudiments, one of which has become a mature sporangium discharging a mass of immobile zoospores (arrow).-Fig. 11-14. Thraustochytrium kerguelensis sp. nov. 11. Mature sporangium. 12. Beginning zoospore liberation. 13. Zoospore liberation in progress. 14. Basal rudiments remaining behind after discharge. 


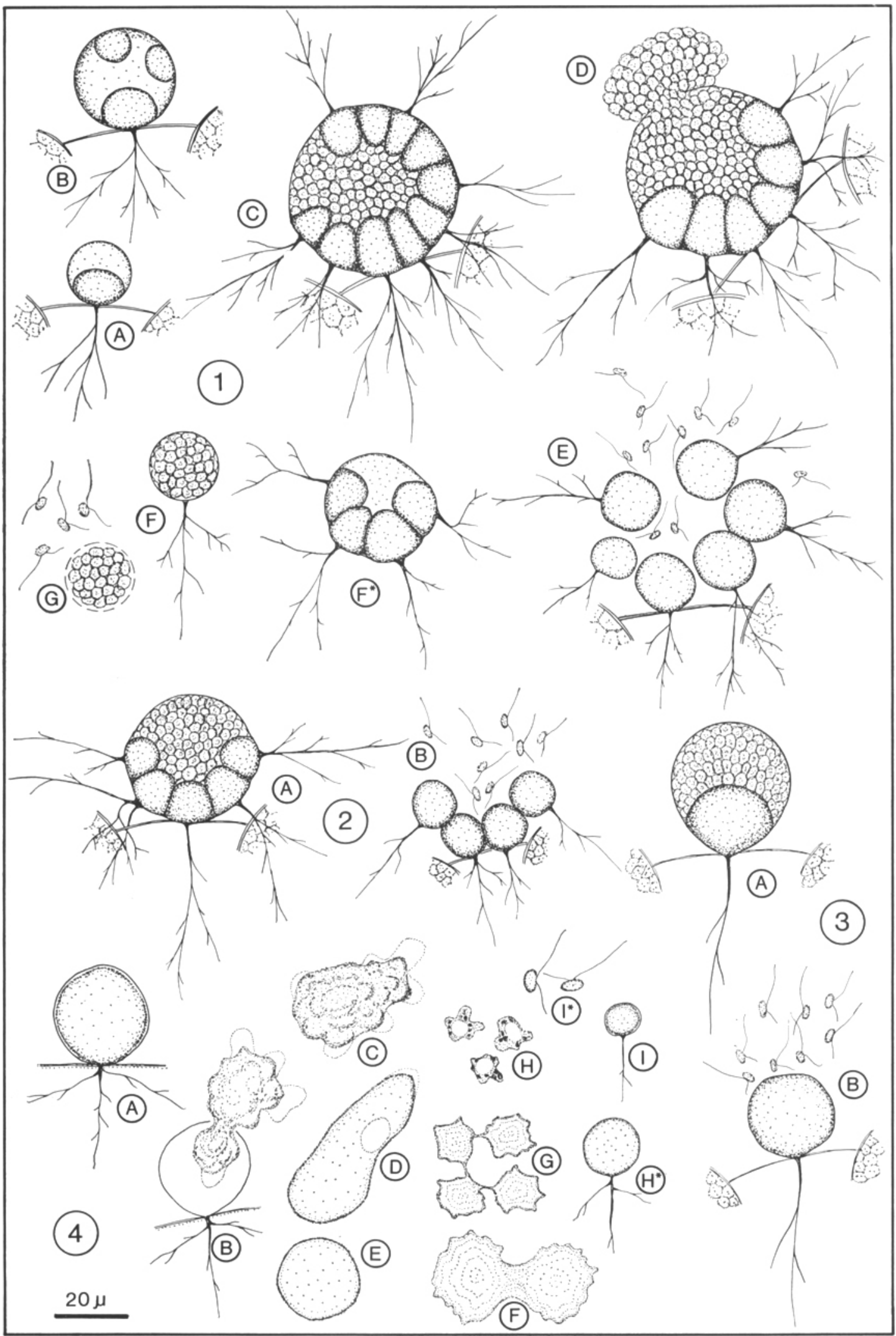




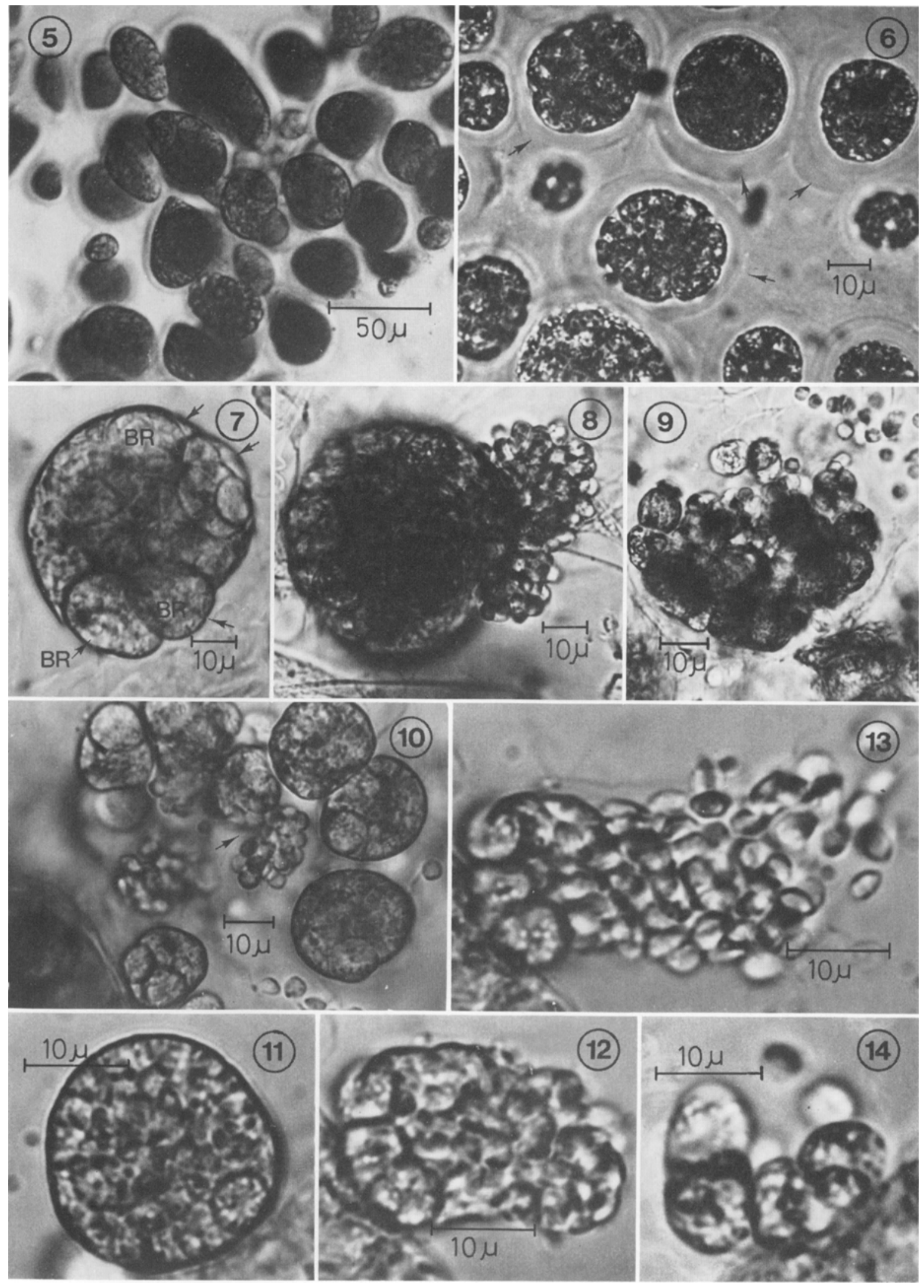


tain several samples from the same depths. In not one case did we find any significant deviation in the number of propagules recovered from different water samples obtained from the same depth.

The nutrient agar was fortified with penicillin $\mathrm{G}$ (sodium) and streptomycin sulfate $(100 \mathrm{mg}$ of each per liter medium) to reduce the growth of bacteria. Single colonies of phycomycetes from filters were streaked on antibiotic-free nutrient agar plates. Isolated colonies were streaked again and colonies from this last plate were used to establish axenic cultures. All phycomycetes studied were obtained in pure culture on nutrient agar plates. For convenience they were maintained (in duplicate) in liquid nutrient medium (composition as for the nutrient agar, with only 1 $\mathrm{g}$ agar per liter medium) as well as on suspensions of pine pollen and brine shrimp larvae in seawater (with $1 \mathrm{~g}$ agar per liter to support floating thalli). For the purpose of identification and elucidation of life cycles, seawater cultures (without agar) were prepared in which pine pollen as well as brine shrimp larvae were used as substrates. Several such set ups in petri dishes were inoculated from pure cultures of liquid nutrient medium as well as from the seawater-pollen-brine shrimp suspensions. Morphological and developmental characters of each species described here did not vary regardless of how the stock cultures were maintained or whether thalli developed on pine pollen or brine shrimp larvae. An exception was Thraustochytrium amoeboidum, which did not grow on pine pollen as a substrate. Morphological and developmental data are derived from observations of the complete development of single thalli in a specially constructed microchamber. ${ }^{3}$

\footnotetext{
${ }^{3}$ Preparation of a microchamber: both sides of a $50 \times 75 \mathrm{~mm}$ microslide are covered with paraffin save for two narrow areas on the mid-long axis of one surface. Each of these is $3 \times 30 \mathrm{~mm}$, and terminates 10 $\mathrm{mm}$ from one another. Hydrofluoric acid $(48 \%)$ is then dropped onto the unprotected glass surface and left for $12-16 \mathrm{hr}$, after which the slide is rinsed off and the depth of the etched grooves measured. If these are less than $0.61 \mathrm{~mm}$, the treatment is repeated until the desired depth is reached. All paraffin is then removed from the slide. A $48 \times 60 \mathrm{~mm}$ No. 1 cover glass is now coated with paraffin save for a $14 \times 14 \mathrm{~mm}$ central area which subsequent hydrofluoric acid treatment dissolves. After removal of the paraffin the cover glass is glued to the grooved central slide surface with clear epoxy resin (a few drops of toluene are added to reduce viscosity) in such a manner that each of the grooves has its opposite ends open, one near the margin of the slide, the other at the depressed center area or "chamber." A $25-\mathrm{cm}$ length of polyethylene tubing (Clay Adams, PE 10,
}

The material in this chamber was continually washed with sterile, aerated seawater and could thus be kept in good condition under observation for several days and even weeks (Bahnweg, 1973). All cultures and microcultures were maintained at $8-10 \mathrm{C}$.

Phycomycetes ReCOVERED-Strains of each of the four new biflagellate, chytrid-like fungi were isolated from subantarctic and antarctic surface waters. They are assigned to the genus Thraustochytrium Sparrow 1936. The other two genera of the Thraustochytriaceae that reproduce by laterally biflagellate zoospores are Japonochytrium Kobayashi \& Ookubo 1953 and Schizochytrium Goldstein \& Belsky 1964. The first is characterized by sporangia having a subsporangial apophysis. Schizochytrium develops tetrads and clusters of sporangia through successive bipartitioning of the thallus before zoospore formation.

Three of the four new fungi develop sporangia which may proliferate from one or more basal rudiments. These are Thraustochytrium antarcticum, T. kerguelensis, and T. rossii. All grow well on both pine pollen and dead brine shrimp larvae. Their morphological and developmental characteristics are the same on either substrate, but brine shrimp larvae are generally more rapidly and more completely colonized than pine pollen.

The fourth new fungus, Thraustochytrium amoeboidum, does not grow on pine pollen, and the description of its life cycle is based entirely on observations of its development on dead brine shrimp larvae.

outer diam $0.61 \mathrm{~mm}$ ) is threaded through one groove, across the chamber area and out through the second groove, after which the two are filled with epoxy resin. Just prior to this action, by slightly raising the tubing in the chamber area the aforementioned resin will be confined to the grooves, an important consideration. After overnight curing the resin $(50-60 \mathrm{C})$ that part of the tubing crossing the chamber is excised. Each free end away from the chamber is now threaded into a 75$80 \mathrm{~cm}$ length of larger polyethylene tubing (Clay Adams, PE $90,0.86 \mathrm{~mm}$ inner diam) and the joints sealed with rubber cement. The microchamber is now ready for use. A small drop of seawater containing the material to be studied is placed in the chamber which is then covered by a $25 \times 25 \mathrm{~mm}$ cover glass with vaseline seal. Small objects like pine pollen grains which float in seawater are better placed in the chamber in drops on cover glass fragments. One free end of the tubing is now placed in a suitably elevated flask half filled with sterile aerated seawater, whereas the other goes into an empty flask placed at a lower level. Careful suction (by mouth) initiates the flow whose rate can be regulated by adjusting the heights of the flasks.

Fig. 15-22. Thraustochytrium amoeboidum sp. nov. 15. Sporangia (Sp) on a dead brine shrimp larva. 16. Mature sporangium; protoplast retracted from sporangium wall and mobile. 17. Protoplast ( $\mathrm{P}=$ pseudopodia) escaping from sporangium $(\mathrm{Sp})$ through a pore $(\mathrm{H}$, slightly below the focal plane) with most of the protoplast already being outside. 18. Pore $(H$, phase dark) on sporangium wall through which protoplast escaped (phase contrast). 19-22. Protoplast moving about as an amoeba $(\mathrm{P}=$ pseudopodia $)$. 


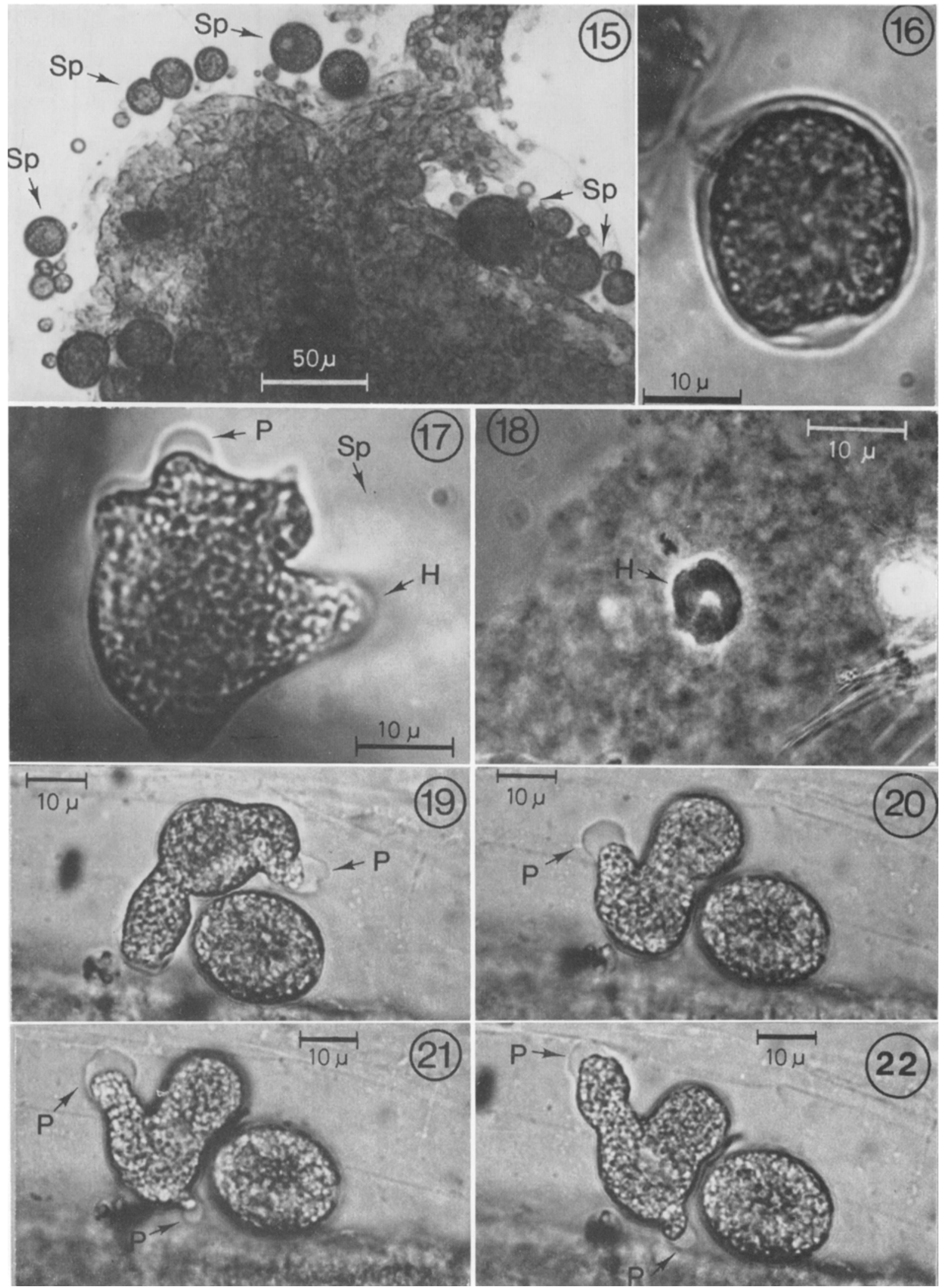


Thraustochytrium antarcticum-Development on pollen or brine shrimp larvae-The ellipsoidal to reniform zoospore $(3 \times 5 \mu \mathrm{m})$ has two laterally inserted flagella. The anteriorly directed flagellum is longer and more active in propelling the spore, which may swim about for several hours before it comes to rest on the substrate. Here it undergoes a period of quivering before becoming completely quiescent, retracting its flagella, and encysting. The zoospore cyst soon produces a delicate rhizoidal system that penetrates the substrate. The young sporangium develops as an enlargement of the zoospore cyst and has a granular protoplast. Upon reaching full size, a single basal rudiment $(8-12 \mu \mathrm{m}$ diam) is delimited before the remainder of the protoplast cleaves into zoospores (Fig. 3A, 29). At discharge the thin sporangium wall disintegrates completely and the group of flagellated zoospores oozes forward, first slowly, then more rapidly. They swim away individually and disperse in all directions (Fig. 3B, 30,32 ), leaving behind an intact basal rudiment which becomes a new sporangium. The diameter of the globose mature sporangium ranges from $18-25 \mu \mathrm{m}$.

Thraustochytrium antarcticum is very similar to T. kinnei Gaertner (1967a) in that its zoospores are flagellated at discharge and the sporangia proliferate internally from a single basal rudiment. In $T$. kinnei, however, the sporangium wall does not disintegrate completely during zoospore liberation as it does in T. antarcticum (Fig. 31, 33); rather, there remains a characteristic "collar" of wall material attached to the basal rudiment. Thraustochytrium antarcticum was isolated from antarctic surface water (at $50 \mathrm{~m}$ depth) at Station 11 of ELTANIN's Cruise 46 (Fig. 34).

Species diagnosis: Thraustochytrium antarcticum sp. nov. ${ }^{4}$ Zoosporangium epibiotic, sessile, globose, $18-25 \mu \mathrm{m}$ diam, wall smooth, thin, color-

\footnotetext{
${ }^{4}$ Thraustochytrium antarcticum sp. nov. Zoosporangium epibioticum, sessile, globosum, 18-25 $\mu \mathrm{m}$ diam, pariete levi tenui incolorato; proliferans ex uno rudimento basali interaneo. Rhizoidale systema endobioticum, ramosum, monaxiale. Zoosporae ellipsoideae vel reniformes, $3 \times 5 \mu \mathrm{m}$; cum duobus flagellis lateralibus a se ex adverso flexis, anticum longius quam posticum; pariete sporangii omnino fatigato confertim liberatae corpora flagellata; quasi confestim mobiles factae abnatant.
}

less, with a single basal rudiment by which internal proliferation is accomplished. Rhizoidal system monaxial, branched. Zoospores ellipsoidal to reniform, $3 \times 5 \mu \mathrm{m}$, with two laterally inserted oppositely directed flagella, the anterior of greater length; discharged as flagellated bodies in a compact clump upon the complete disintegration of the sporangium wall, almost instantly assuming individual motility and swimming away.

This description plus the Fig. $3 \mathrm{~A}, \mathrm{~B}$, and 29 33 represent the type of Thraustochytrium antarticum (cf. article 9 of the 1972 ed. of the Int. Code of Bot. Nomenclature).

Thraustochytrium rossii-Development on pollen or brine shrimp larvae-The young sporangium develops from an encysted zoospore by enlargement. It may or may not reach the size of a mature sporangium before a series of basal rudiments is delimited. Such rudiments are formed successively as long as the remainder of the protoplast has not cleaved into zoospores (Fig. 1A, B). A total of 5 to 50 proliferating rudiments may be formed in each sporangium (Fig. 1C, 7, 9). Mature sporangia may attain considerable size (up to $80 \mu \mathrm{m}$ diam, generally $40-50 \mu \mathrm{m}$ diam); the basal rudiments measure $8-15 \mu \mathrm{m}$ diam. Rhizoids are at first found to originate from only one portion of the young sporangium. As more and more basal rudiments are delimited, however, an extensive network of branched rhizoids which is apparently associated with the basal rudiments (Fig. 1C) is formed. At maturity upon disintegration of a small part of the wall, a portion of the individually quiescent spores oozes out of the sporangium (Fig. 1D, 8). This mass of zoospores is continuous with those remaining inside the sporangium and all are quiescent for 3 $12 \mathrm{hr}$ before individual zoospores become flagellated and swim away. By the time the spores become flagellated, the entire sporangium wall has disintegrated and a cluster of individual basal rudiments remains behind (Fig. 1E, 9). The rudiments may enlarge, each one becoming a new sporangium with new basal rudiments inside (Fig. $1 \mathrm{~F}^{*}, 10$ ), or may exhaust themselves, especially smaller rudiments, in the formation of zoospores (Fig. 1F, G). Zoospores are liberated and assume motility as before. They are $2.5-3.5 \mu \mathrm{m}$

Fig. 23-33.-Fig. 23-28. Thraustochytrium amoeboidum sp. nov. 23. Protoplast displaying euglenoid movements $(\mathrm{V}=$ vacuole $)$. 24. Rounded up protoplast. 25. Dividing protoplast (2nd division). 26. Dividing protoplast (2nd division, advanced). 27. Protoplast after several divisions; daughter cells remain connected for awhile by plasma filaments (F). 28. Small amoeboid spore (A) with a prominent vacuole (V); encysted amoebae form rhizoid ( $R$ ) and develop into new sporangia (Sp).- Fig. 29-33. Thraustochytrium antarcticum sp. nov. 29. Mature sporangia. 30. Zoospore discharge in progress; rudiment on left. 31. Basal rudiment after zoospore liberation. 32. Zoospore discharge of another sporangium. 33. Basal rudiment (BR) stained with phloxine immediately after zoospore liberation. No remnants of sporangial wall material adhering to the basal rudiment are detectable in this way $(Z=$ zoospore $)$. 


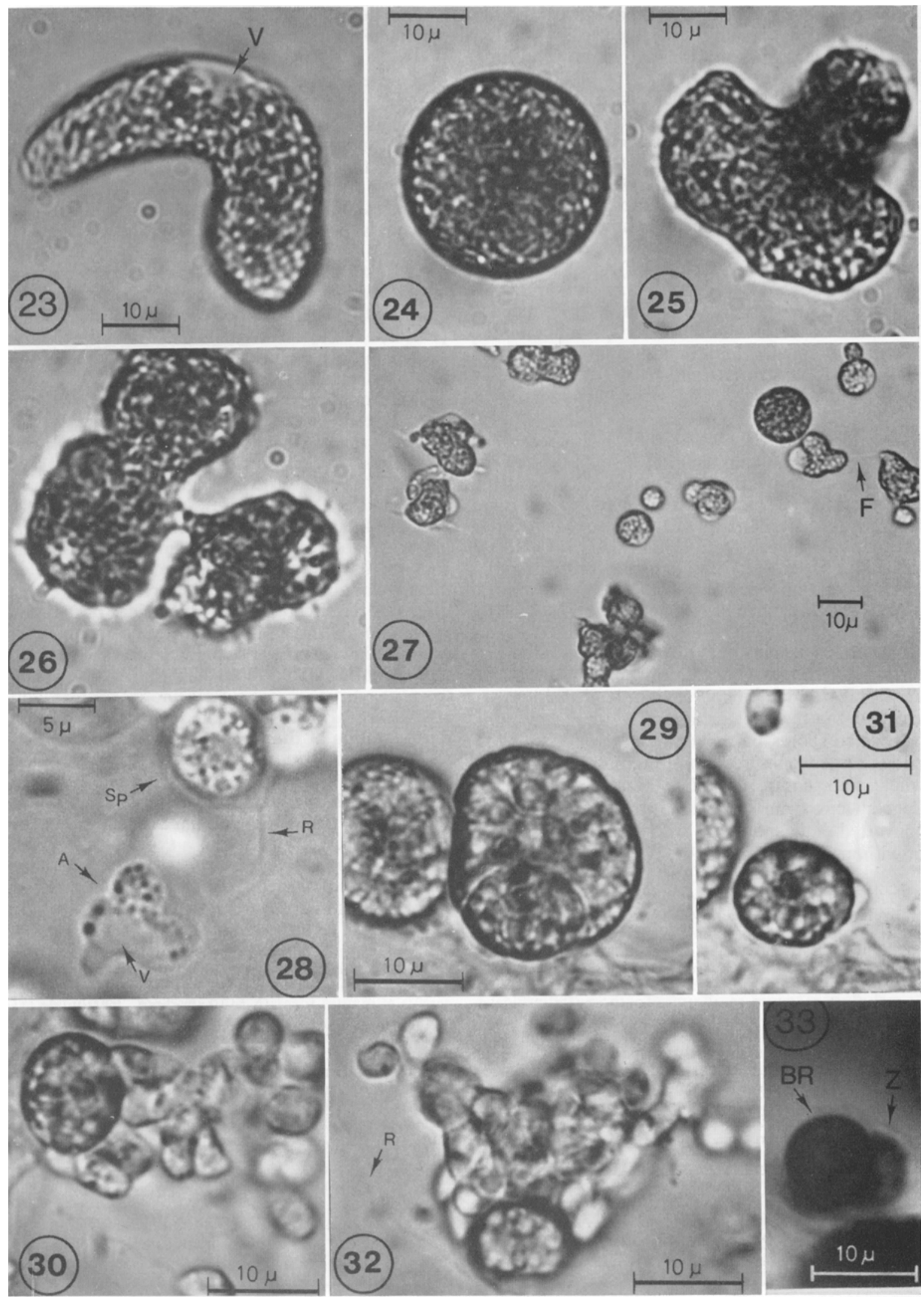


wide and $4.8-5.5 \mu \mathrm{m}$ long and have two laterally inserted flagella of which the forwardly directed one is longer, thicker, and active in propelling the spore.

Thraustochytrium rossii was isolated from antarctic surface water (surface and $100 \mathrm{~m}$ depth) at Station 14, Cruise 51 (Fig. 35), near the edge of the Ross Ice Shelf. Thraustochytrium rossii is similar to T. multirudimentale Goldstein (1963) in that it proliferates from more than one basal rudiment. Goldstein's species, however, is quite different in several respects. It forms only a small number (usually 2, rarely 3-4) of basal rudiments; the zoospores are motile at discharge; the lower portion of the sporangium wall is persistent and remains behind after zoospore liberation.

On agar media and in liquid nutrient broth thalli of Thraustochytrium rossii develop thick hyaline sheaths (Fig. 5,6).

Species diagnosis: Thraustochytrium rossii sp. nov. ${ }^{5}$ Zoosporangium epibiotic, sessile, globose, 40-50 $\mu \mathrm{m}$ diam, wall smooth, thin, colorless, with a series (6-50) of basal rudiments successively cleaved from sterile parts of the protoplasm which become themselves thalli with rhizoidal systems. Rhizoidal system at first monaxial but with rudiment formation becoming an extensive network of branched elements. Zoospores ellipsoidal to reniform, $2.5-3.5 \mu \mathrm{m} \times 4.8-5.5 \mu \mathrm{m}$, with two laterally inserted oppositely directed flagella, the anterior one the longer and thicker; at discharge an apical part of the sporangium wall disintegrating and the mass of individually quiescent nonflagellated spores partially emerging and, with the undischarged ones remaining nonmotile $3-12 \mathrm{hr}$; when wall completely disintegrates, they form flagella and swim individually away. Rudiments converted into sporangia with rhizoids and with or without new rudiments.

\footnotetext{
Thraustochytrium rossii sp. nov. Zoosporangium epibioticum, sessile, globosum, $40-50 \mu \mathrm{m}$ diam, pariete levi tenui incolorato; cum compluribus $(6-50)$ rudimentis basalibus formatis successive ex partibus sterilibus protoplasti, quae ipsa fiunt systematibus rhizoidalibus. Rhizoidale systema primo monaxiale, sed rudimentis formatis fit reticulum magnum ramosum. Zoosporae ellipsoideae vel reniformes, $2.5-3.5 \mu \mathrm{m} \times 4.8-5.5 \mu \mathrm{m}$, cum duobus flagellis lateralibus a se ex adverso flexis, anticum longius et crassius quam posticum; parte apicali parietis sporangii fatigata, quiescentes 3-12 horis et aflagellatae, partim emergunt, partim remanent; pariete omnino fatigato liberatae flagellis factis singulatim abnatant. Rudimenta sporangia fiunt cum rhizoideis partim rudimenta nova habentia, partim non.
}

This description plus the Fig. $1 \mathrm{~A}-\mathrm{G}$ and $5-10$ represent the type of Thraustochytrium rossii.

Thraustochytrium kerguelensis sp. nov.-Development on pollen or brine shrimp larvae-The protoplasm of the young globose thallus is granular. Basal rudiments are successively delimited early in the development. A total of 3-10 proliferating rudiments is formed. Mature sporangia measure $20-30 \mu \mathrm{m}$ diam, globose or subglobose rudiments $6-10 \mu \mathrm{m}$ diam. Flagellated zoospores $(2.5-3 \times 5-7 \mu \mathrm{m})$ with two laterally inserted flagella ooze en masse away from the basal rudiments upon complete disintegration of the sporangium wall, then quickly swim away individually (Fig. 2, 12, 13). The rudiments remaining behind (Fig. 14) develop into new sporangia with (often) fewer basal rudiments.

Thraustochytrium kerguelensis was isolated from waters (at $90 \mathrm{~m}$ depth) near the subantarctic Kerguelen Islands at Station 17, Cruise 46 (Fig. 34). Thraustochytrium kerguelensis is similar to $T$. rossii and to $T$. multirudimentale Goldstein in that it proliferates from more than one basal rudiment. It differs from the latter in the larger number of basal rudiments and in that the wall of its sporangium disintegrates completely during liberation of the zoospores. In $T$. rossii discharge is effected when the apical part of the sporangium disintegrates and the mass of quiescent nonflagellated spores partially emerges. They remain nonflagellated until the entire wall disintegrates. In $T$. kerguelensis, however, the zoospores are already flagellated upon the uniform disintegration of the wall.

Thraustochytrium kerguelensis $\mathrm{sp}$. nov. ${ }^{6} \mathrm{Zoo}-$ sporangium epibiotic, sessile, globose, $20-30 \mu \mathrm{m}$ diam, with thin, smooth, colorless wall, and 3-10 successively and early delimited basal rudiments $6-10 \mu \mathrm{m}$ diam; rhizoidal system monaxial, branched, becoming complex upon rudiments forming extramatrical rhizoidal systems. Zoospores ellipsoidal to reniform, $5-7 \times 2.5-3 \mu \mathrm{m}$,

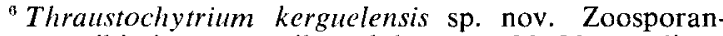
gium epibioticum, sessile, globosum, 20-30 $\mu \mathrm{m}$ diam. pariete levi tenui incolorato, cum 3-10 rudimentis successive et mature formatis $6-10 \mu \mathrm{m}$ diam. Rhizoidale systema primo monaxiale, ramosum, rudimentis systemata rhizoidalia propria extra matricem formantibus, complexum. Zoosporae ellipsoideae vel reniformes, $5-7 \mu \mathrm{m}$ $\times 2.5-3 \mu \mathrm{m}$, cum duobus flagellis lateralibus a se ex adverso flexis, anticum longius quam posticum; pariete sporangii omnino fatigato confertim liberatae corpora flagellata celeriter abnatant. Rudimenta sporangia nova fiunt cum paucioribus rudimentis basalibus.
}

Fig. 34-36. 34. Cruise track of ELTANIN's Cruise 46 in the southeastern Indian Ocean. Blackened circles indicate phycomycete propagules in water, half blackened circles in water as well as in sediment samples. 35. Cruise track of ELTANIN's Cruise 51. 36. Distribution of phycomycete propagules in the water column at selected stations of ELTANIN's Cruises 46 and 51. 

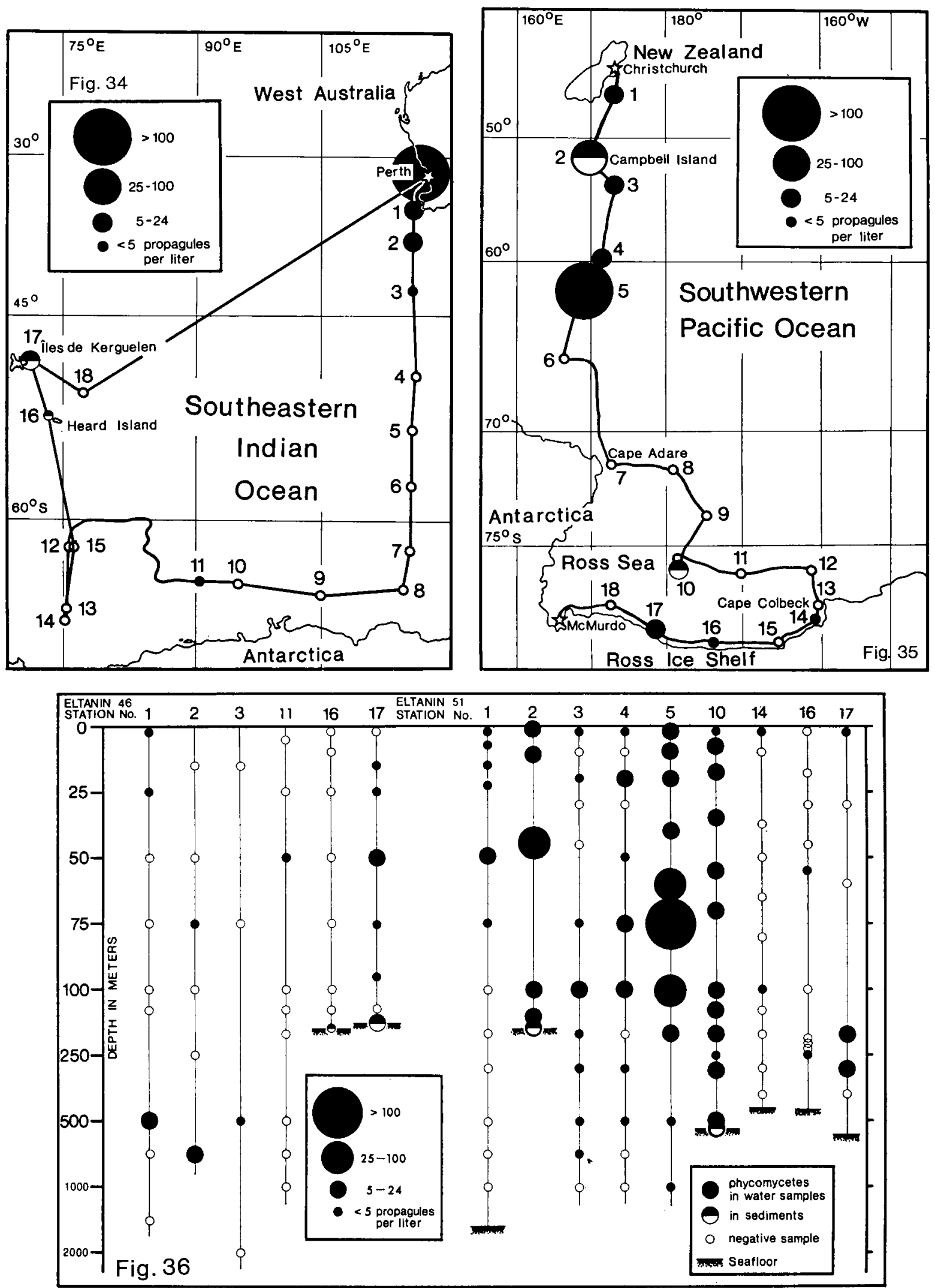
with two laterally inserted oppositely directed flagella, the anterior the longer; discharged as a cluster of flagellated bodies upon complete disintegration of sporangial wall and quickly swimming away; rudiments forming new sporangia with fewer basal rudiments.

This description plus the Fig. 2A, B, and 11-14 represent the type of Thraustochytrium kerguelensis.

Thraustochytrium amoeboidum sp. nov.-Development on brine shrimp larvae-Mature epibiotic sporangia are globose, subglobose to broadly ellipsoid and measure $20-25 \mu \mathrm{m}$ diam (Fig. 4A, 15, 16). They are anchored to the substrate by branched rhizoids. At maturity the granulated protoplasm retracts slightly from the sporangial wall (Fig. 16) and the protoplast starts to move around inside the sporangium. It then leaves the sporangium by squeezing itself actively through a pore in the otherwise persistent sporangium wall (Fig. 4B, 17, 18). The protoplast moves about like an amoeba for several minutes (occasionally up to an hour; Fig. 4C, 19-22) before its outer membrane becomes more rigid and allows only a euglenoid type of movement (Fig. 4D, 23). Eventually the protoplast rounds up (Fig. $4 \mathrm{E}, 24)$ and after resting for only a few minutes starts to divide (Fig. 4F, 25-27). The daughter cells do not remain in a cluster but separate into individual cells. These, however, remain connected for a long time by thin delicate strands of protoplasm (Fig. 4G, 27). Up to 64 small cells may be formed through successive divisions. Daughter cells may, after any one division, develop directly into new sporangia, even while their sister cells continue to divide (Fig. $4 \mathrm{H}^{*}$ ). The "end product" of several successive divisions is small spores (Fig. 4H, 28) which may crawl around like amoebae for awhile; these encyst, form rhizoids, and develop into new sporangia (Fig. 4I, 28). Infrequently, zoospores were observed (Fig. 4I). At first considered a contaminant, they were later found in all 25 isolates of this fungus, and also in 50 single spore isolates prepared from one strain. The zoospores $(2.5-3.5 \times 5-6.5$ $\mu \mathrm{m})$ are ellipsoid to ovoid and have two laterally inserted flagella. The anteriorly directed one is long $(8-12 \mu \mathrm{m})$ and thick, while the posterior is shorter, thinner, and often very difficult to see. Under observation the zoospores round up rapidly, losing rather than retracting their anterior flagellum. The fate of the posterior flagellum could not be determined with certainty. The rounded-up zoospore may develop rhizoids, or produce pseudopodium-like outgrowths. The origin of the zoospores and their place in the life cycle of this fungus were not determined. They were, however, present in all brine shrimp larvae cultures, though always in low numbers, and undoubtedly belong to the fungus.

Thraustochytrium amoeboidum was isolated from subantarctic waters south of New Zealand at Stations 1-3, Cruise 51 (Fig. 35). It is some. what similar to $T$. visurgense Ulken (1965) in that its protoplast is capable of amoeboid movement after leaving the sporangium. In the latter species, however, the protoplast is liberated passively by distintegration of the sporangial wall and zoospores rather than amoebospores are produced. Colonies of Thraustochytrium amoeboidum on agar are brightly colored deep orange to scarlet red.

Species diagnosis: Thraustochytrium amoeboidum $\mathrm{sp}$. nov. ${ }^{7}$ Zoosporangium epibiotic, sessile, globose, subglobose to broadly ellipsoid, 20 $25 \mu \mathrm{m}$ diam, with thin, smooth, colorless wall. Rhizoidal system monaxial, branched. Discharge accomplished by formation of an apical or subapical pore through which the previously amoeboidly moving sporangial contents passes to the outside as an amoeboid mass where it becomes more rigid and undergoes euglenoid movement; sporangial mass then becoming quiescent, rounding up and dividing successively into numerous (up to 64) daughter cells, remaining at first connected by delicate protoplasmic strands, later becoming separated into individual amoeboid spores (3.5-5 $\mu \mathrm{m}$ diam) which after a period of crawling encyst, develop rhizoids, and become new sporangia; ellipsoidal to ovoid biflagellate zoospores $(2.5-3.5 \times 5-6.5 \mu \mathrm{m})$ also observed but part in life history at present unknown.

This description plus the Fig. 4 A-I, and 1528 represent the type of Thraustochytrium amoeboidum.

Thraustochytrium amoeboidum is rather differferent from other thraustochytrids with respect to several characters: (1) the peculiar way in which the protoplast divides (Fig. 25-27); (2) the production of amoebospores; (3) the inability of this fungus to develop reproductive units on pine pollen as a substrate. Some developmental characters of this new fungus are somewhat similar to Labyrinthuloides yorkensis Perkins (1973b), namely, the

'Thraustochytrium amoeboidum sp. nov. Zoosporangium epibioticum, sessile, globosum, subglobosum vel late ellipsoideum, $20-25 \mu \mathrm{m}$ diam, pariete levi tenui incolorato. Rhizoidale systema monaxiale, ramosum. Antea velut amoeboideus movens protoplastus sporangii, per apicalem aut subapicalem porum nuper formatum similiter evadit ultra sporangium, ubi rigescit, velut euglenoideus movens; tum quiescens et sphaericus, postea successive dividens in multis (ad 64) cellulis filialibus, primo connexis tenuibus filamentis protoplasmaticis, demum separantibus in singulis sporis amoeboideis $3.5-$ $5 \mu \mathrm{m}$ in diam, quae, postquam repunt, encystant, et rhizoideis formatis nova sporangia fiunt. Zoosporae biflagellatae, ellipsoideae vel ovoideae, $2.5-3.5 \mu \mathrm{m} \times 5$ $6.5 \mu \mathrm{m}$, etiam observantur, sed quas partes agant nescitur. 
production of small amoeboid spores, infrequent occurrence of biflagellate zoospores, and the ability of cells of all sizes to divide, presumably following nuclear division, by pinching and pulling in half. Indeed, Thraustochytrium amoeboidum may well turn out to be a link between the thraustochytrids and the labyrinthulids should it indeed prove true that these two groups of fungal organisms are as closely related as indicated recently by the discovery of common ultrastructures, sagenogenetosomes and ectoplasmic nets (Perkins, 1972).

DISTRIBUTION OF PHYCOMYCETES IN THE SUBANTARCTIC AND ANTARCTIC MARINE ECOSYSTEMS -As already mentioned, all of the phycomycetes recovered from antarctic and subantarctic marine waters and sediments belong to the family Thraustochytriaceae. Yet not one of the species described from north of the Antarctic Convergence was found. This may possibly indicate the presence of an endemic flora of thraustochytrioid phycomycetes in the harsh antarctic marine ecosystems where water temperatures may be as low as $-1.9 \mathrm{C}$. In spite of the generally low temperatures of antarctic $(-2.0$ to about $+4.0 \mathrm{C})$ and subantarctic $(3.0-10.0 \mathrm{C})$ waters, substantial phycomycete populations were detected, particularly during ELTANIN's Cruise 51 (Fig. 35) when the glass fiber filtering technique (Bahnweg, 1973) was employed to enumerate fungal propagules in water samples. Phycomycete populations at the subantarctic Stations 1-3 of Cruise 51 (Fig. 35) were made up of Aplanochytrium kerguelensis Bahnweg \& Sparrow (1972b), Thraustochytrium amoeboidum sp. nov., and, in bottom sediments at Station 2 near Campbell Island, Schizochytrium sp. Populations of an unidentified Thraustochytrium were found at Stations 4 and 5 (Cruise 51) in antarctic waters south of the Antarctic Convergence (Polar Front). At least two different and as yet unidentified species of Thrautochytrium were found at Station 10, 16, and 17 in the Ross Sea (Fig. 35). Phycomycetes found at Station 14 in the Ross Sea all belong to Thraustochytrium rossii $\mathrm{sp}$. nov. On ELTANIN's Cruise 46 (Fig. 34) phycomycetes were found in subtropical waters (at the coast of West Australia, and at Stations 1-3). Thraustochytrium antarcticum sp. nov. was found at Station 11 in antarctic waters while A planochytrium kerguelensis Bahnweg \& Sparrow and Thraustochytrium kerguelensis $\mathrm{sp}$. nov. were found near the antarctic Heard Island and the subantarctic Kerguelen Islands (Stations 16 and 17, respectively).

The two cruises of the ELTANIN to the Antarctic not only made possible the study of the mycoflora of waters previously uninspected by mycologists but also provided a unique opportunity to study phycomycetes in the open ocean far away from continents or islands. Thus the presence of large populations of phycomycetes independent of any terrestrial influence was discovered in antarctic waters south of the Antarctic Convergence at Stations 4 and 5 of Cruise 51 (Fig. 35). High numbers of phycomycetous propagules were detected near continents or islands in the subtropical and subantarctic regions (coast of West Australia, Stations 1,2, 3, 16, and 17 of Cruise 46, Fig. 34; Station 2 of Cruise 51, Fig. 35). Such a relationship between the occurrence of phycomycetes and the presence of land masses was not found to exist in antarctic regions. This is probably due to the fact that runoff from the barren antarctic islands and the Antarctic continent itself does not carry with it much plant debris and other organic substances which might serve as substrates for saprophytic marine fungi.

Phycomycete population densities at each station where such populations were detected are plotted against depth in Fig. 36. Highest numbers of propagules were generally found in the surface layers of the ocean $(25-250 \mathrm{~m})$ somewhat below the photic zone, the lower limit of which ranged between 30 and $60 \mathrm{~m}$. Phycomycetes were found only four times in bottom sediments of shallow waters at Stations 16 and 17 (Cruise 46) and 2 and 10 (Cruise 51). The peculiar distribution of phycomycetes in the water column may indicate that they are engaged in decomposing substances produced in the photic zone. Their exact role in the marine ecosystems, however, remains to be determined by precise physiological studies.

\section{LITERATURE CITED}

Artemtchuk, N. F. 1972. The fungi of the White Sea. III. Phycomycetes, discovered in the Great Sama Strait of the Kandalakshial Bay. Veröff. Inst. Meeresforsch. Bremerhaven 13: 231-237.

BAHNWEG, G. 1973. The occurrence, distribution and taxonomy of fungi, in particular lower phycomycetes, in the subantarctic and antarctic marine ecosystems. Ph.D. thesis, the University of Michigan, Ann Arbor.

ANd F. K. Sparrow. 1971. Marine fungi: oc currence in the southern Indian Ocean. Antarct. J. U. S. 6: 155 .

AND 1972a. Marine fungi: their occurrence south of New Zealand and in the Ross Sea. Antarct. J. U. S. 7: 177-178.

- AND - 1972b. Aplanochytrium kerguelensis gen. nov. spec. nov., a new phycomycete from Subantaretic marine waters. Arch. Mikrobiol. 81: 45-49.

Fuller, M. S., B. E. Fowles, and D. J. Mclaughlin. 1964. Isolation and pure culture studies of marine phycomycetes. Mycologia 56: 745-756.

GafrTnER, A. 1967. Ökologische Untersuchungen an einem marinen Pilz aus der Umgebung von Helgoland. Helgol. Wiss. Meeresunters. 15: 181-192. 
1968a. Eine Methode des quantitativen Nachweises niederer, mit Pollen köderbarer Pilze im Meerwasser und im Sediment. Veröff. Inst. Meeresforsch. Bremerhaven Sonderbd. 3: 75-92. - 1968b. Niedere, mit Pollen köderbare marine Pilze diesseits und jenseits des Island-Färöer-Rückens im Oberflächenwasser und im Sediment. Veröff. Inst. Meeresforsch. Bremerhaven 11: 6582.

1968c. Die Fluktuationen mariner niederer Pilze in der Deutschen Bucht 1965 und 1966. Veröff. Inst. Meeresforsch. Bremerhaven Sonderbd. 3: $105-120$.

- 1969. Marine niedere Pilze in Nordsee und Nordatlantik. Ber. Dtsch. Bot. Ges. 82: 287-306.

GoldSTEIN, S. 1963. Development and nutrition of new species of Thraustochytrium. Amer. J. Bot. 50: 271-279.

, AND M. BELSKY. 1964. Axenic culture studies of a new marine phycomycete possessing an unusual type of asexual reproduction. Amer. J. Bot. 51: 72-78.

Harder, R., and I. Persiel. 1962. Notiz über das Vorkommen niederer Erdphycomyceten in der Antarktis. Arch. Mikrobiol. 41: 44-50.

HöHNK, W. 1966. Weitere Daten zur Verbreitung der marinen Pilze. Veröff. Inst. Meeresforsch. Bremerhaven Sonderbd. 2: 209-220.

Kobayashi, Y., AND M. Ookubo. 1953. Studies on the marine phycomycetes I. Bull. Nat. Sci. Mus. (Tokyo) 33: 53-65.

Niskin, S. J. 1962. A water sampler for microbiological studies. Deep-Sea Res. 9: 501-503.

Paterson, R. A., AND J. S. KNox. 1972. The occurrence of aquatic fungi in Victoria Land and Ross Island, p. 185-192. In: Parker, B. C. [ed.]. Conservation problems in Antarctica (Proceedings of a Colloquium). Blacksburg, Virginia.

, AND H. RoONEY. 1972. Aquatic fungi: their occurrence in the McMurdo oasis. Antarct. J. U. S. 7: 85 .
Perkins, F. O. 1972. The ultrastructure of holdfasts, "rhizoids" and "slimetracks" in thraustochytriaceous fungi and in Labyrinthula spp. Arch. Mikrobiol. 84: 95-118.

1973a. Observations of thraustochytriaceous (Phycomycetes) and labyrinthulid (Rhizopodea) ectoplasmic nets on natural and artificial substrates -an electron microscope study. Can. J. Bot. 51 : $485-491$.

. 1973b. A new species of marine labyrinthulid Labyrinthuloides yorkensis gen. nov. et sp. nov.Cytology and fine structure. Arch. Mikrobiol. 90: $1-17$.

SchneIDER, J. 1968. Über niedere Phycomyceten der westlichen Ostsee. Veröff. Inst. Meeresforsch Bremerhaven Sonderbd. 3: 93-104.

-1971. Niedere Pilze aus Bodenproben des Brack- und Meerwassers der englischen Westküste. Kieler Meeresforsch. 27: 94-101.

Sparrow, F. K. 1936. Biological observations on the marine fungi of Woods Hole waters. Biol. Bull. 70: $236-263$.

-1968. On the occurrence of the Thraustochytriaceae. Veröff. Inst. Meeresforsch. Bremerhaven 11: 89-92.

1969. Zoosporic marine fungi from the $\mathrm{Pa}$ cific Northwest, U.S.A. Arch. Mikrobiol. 66: 129146.

Suglyama, J., Y. SugiYama, H. IIzUKa, and T. Torit. 1967. Reports of the Japanese summer parties in Dry Valleys, Victoria Land, 1963-1965. IV. Mycological studies of the Antarctic fungi. Part 2. My coflora of Lake Vanda, an ice-free lake. Antarct. Record (Tokyo) 28: 2247-2256.

Ulkes, A. 1965. Zwei neue Thraustochytrien aus der Aussenweser. Veröff. Inst. Meeresforsch. Bremerhaven 9: 289-295.

—. 1966. Untersuchungen über marine Pilze im äquatorialen Atlantik vor der Küste Brasiliens. Veröff. Inst. Meeresforsch. Bremerhaven 10: 107116. 